\title{
Smelt spout corrosion in a recovery boiler
}

\author{
JULIO CÉSAR TÔRRES RIBEIRO, MARCELO CARDOSO, AND HONGHI TRAN
}

\begin{abstract}
Severe corrosion led to an in-service failure of one of the six spouts on a recovery boiler at Cenibra. The failure resulted in a large amount of cooling water entering the boiler and contacting smelt around the spout opening, but fortunately no smelt-water explosion occurred. An extensive investigation was conducted to determine the causes of the spout failure. The failure was caused by insufficient cooling water flow to the smelt spout, which, in turn, was caused by a sequence of events that occurred after a general blackout of an electrical energy system at the mill. The experience has led to the development and placement of operating and maintenance procedures that ensure adequate cooling water flows to smelt spouts to prevent future failures.
\end{abstract}

Application: Mills can revise operating and maintenance procedures to prevent failure of recovery boiler spouts.

C elulose Nipo-Brasileira S.A. (Cenibra) is a 1.2-million a.d. metric tons/year bleached eucalyptus kraft pulp mill located near the city of Ipatinga, $250 \mathrm{~km}$ south of Belo Horizonte, Minas Gerais State, Brazil. The mill has two pulp production lines and three recovery boilers. The No. 1 recovery boiler (RB) was built in 1976. It has a firing capacity of 1800 metric tons of black liquor dissolved solids per day but is presently in a standby condition. The No. 2 RB was built in 1992 and presently burns 2700 metric tons of black liquor dissolved solids per day at $72 \%$ solids. The No. $3 \mathrm{RB}$, the newest and largest of the three, started up in 2006 and burns 3500 metric tons of black liquor dissolved solids per day, also at $72 \%$ solids. These

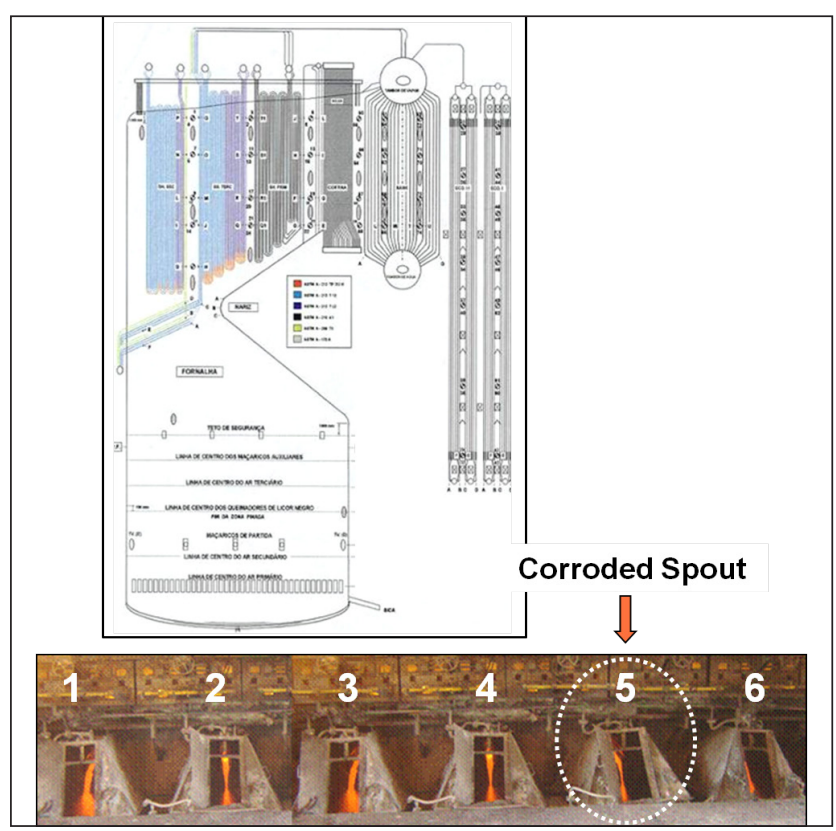

1. Schematic drawing of the No. 2 RB and smelt spout identifications.

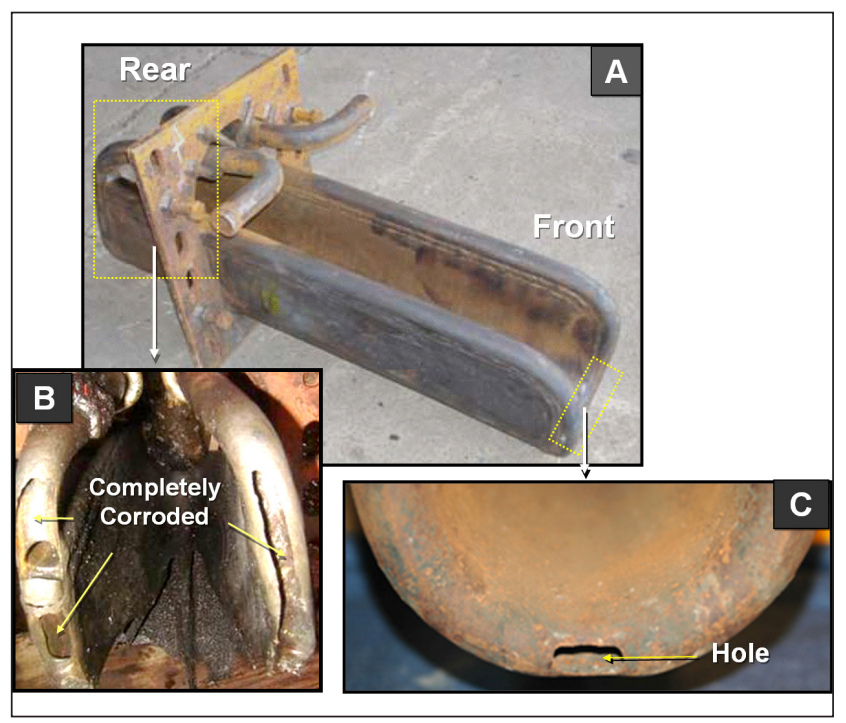

2. Large perforations at the rear and a hole at the front lip of the severely corroded spout No. 5.

three boilers produce superheated steam rated at 65 bars and $450^{\circ} \mathrm{C}$, and they were all supplied by $\mathrm{CBC}$, a Mitsubishi Heavy Industries branch in Brazil.

The mill's electrical power is supplied by two turbo-generators ( 40 and $60 \mathrm{MW}$ ) and by the grid $(9.5 \mathrm{MW})$. The generators operate in island mode and are not directly connected to the grid. Since its startup in 1976, the mill had never had an emergency shutdown procedure (ESP). In February 2008, one of six smelt spouts of the No. 2 RB failed (Fig. 1). This spout, No. 5, was so severely corroded that water was leaking out and coming into contact with molten smelt. Figure 2 shows a large hole at the spout lip (front end) and multiple layers of large perforations along the inlet and outlet coolingwater tubing on the furnace side (rear end) of the spout.

The ESP occurred 7 days after a total mill-wide power fail- 
ure that disrupted operations. Fortunately, the incident did not lead to a smelt-water explosion. However, the severity of the problem and the potential damage it might have caused prompted the mill to conduct an extensive investigation to determine the causes of the spout failure. This investigation involved documentation of the sequence of events, analysis of relevant process data, nondestructive testing of all smelt spouts, and metallurgical analysis of corroded and noncorroded sections of the failed spout. We discuss the smelt spout system, the key findings of the investigation, the connection between the power failure and the smelt spout leak, the underlying reasons why the failure occurred, and the steps taken to prevent a recurrence.

\section{SMELT SPOUT SYSTEM}

The No. 2 RB originally had only five smelt spouts. Spout No. 6 was added to handle the increased smelt flow after a major retrofit of the boiler in 2004 to increase its firing capacity from 2050 to 2700 metric tons of black liquor dissolved solids per day. At that time, all six smelt spouts were relocated to new positions.

The spouts, which were supplied by the same boiler manufacturer (CBC), are made of carbon steel with no weld overlay and inserted into the boiler (Fig. 2). All three recovery boilers use the same type and model of spouts, which are essentially the same as the original design that was used in 1976. Over the years, the mill has been following Black Liquor Recover Boiler Advisory Committee (BLRBAC) operation procedures to discard all smelt spouts and replace them with a new set of spouts every year, regardless of their condition [1]. The spouts have always been found to be in good condition after 1 year in service, with no excessive thinning or corrosion.

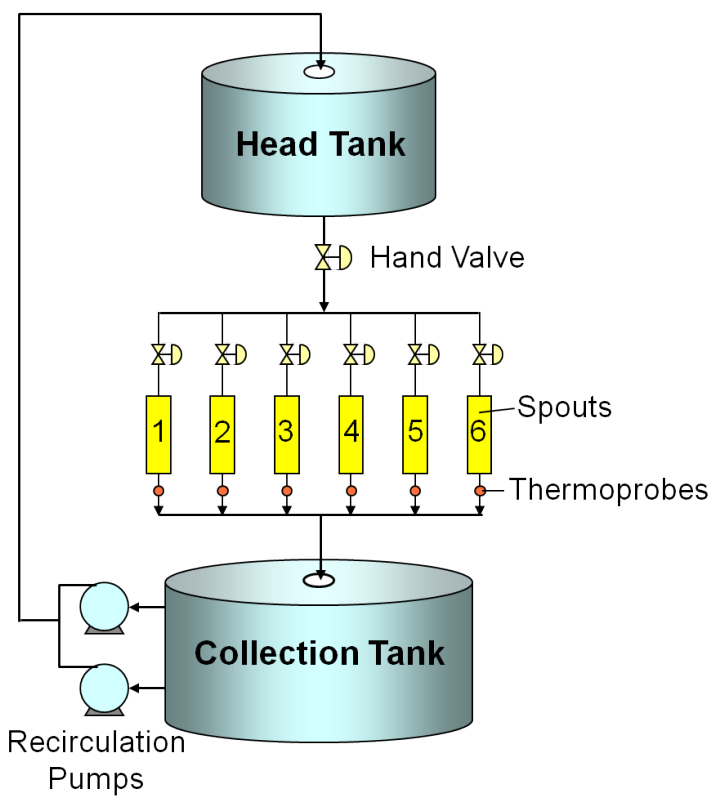

3. No. 2 RB smelt spout cooling water system.

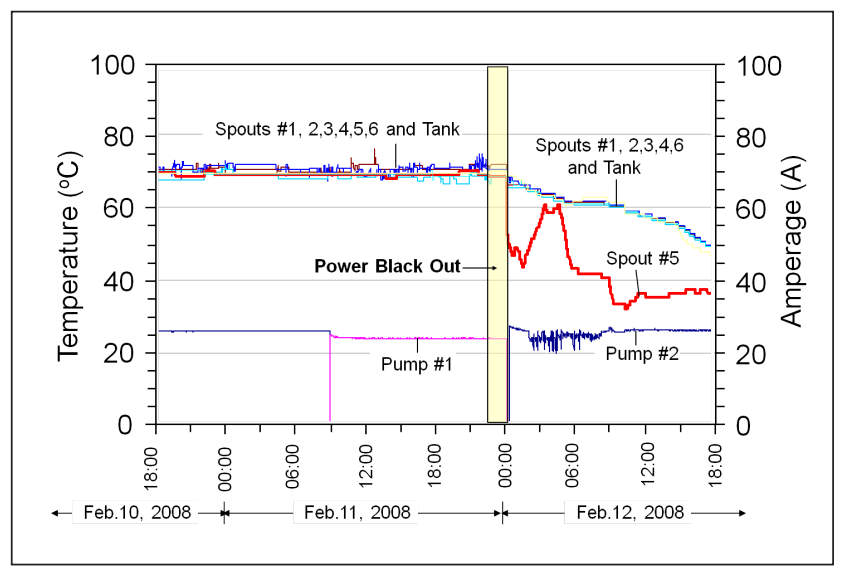

4. Cooling water trend before and after the blackout period.

This specific set of the No. 2 RB smelt spouts had been in service for 10 months at the time of the incident.

The smelt cooling water system is a typical pressurized, closed-loop system using high-quality treated water, as shown in Fig. 3. The main components are a head tank, piping to and from the individual smelt spouts, hand valves, a collection tank, and dual recirculation water pumps to transfer the cooling water back to the head tank. There are no flowmeters on the lines to the individual spouts. Although cooling water flow could be visually verified through glass doors installed on individual spout pipelines, this did not usually occur, because the glass doors were small and often dusty and were mounted in an obscure position that was difficult to access. The primary means for verifying their proper operation was monitoring the cooling water temperature discharging from each spout with a thermoprobe through a distributed control system (DCS). A hand valve (normally wide open) is in the main cooling water line leaving the head tank. This main line is $\mathrm{di}-$ vided into six smaller lines, one to each spout with a separate shutoff valve to isolate the cooling water to that spout in the event of a spout leak. Because the system at the time of the incident did not have the capability of adding firewater to the head tank in the event of a power failure, the loss of electrical power meant that recirculation pumps were unable to continue delivering water to the head tank, which eventually ran out of cooling water.

\section{SEQUENCE OF EVENTS}

\section{February 11, 2008 (blackout)}

The No. 2 RB was operating normally until 9:02 P.M., when a general electrical power blackout occurred due to a short circuit in turbo-generator No. 1 . The short circuit caused most emergency systems to fail, including the grid power and backup diesel generators. The mill had no electrical power for 71 min. The power failure caused the boiler to trip, but smelt continued to flow out of the furnace for some time after the boiler trip.

The loss of power also caused both recirculation pumps to stop, thereby shutting off the return cooling water flow to the 


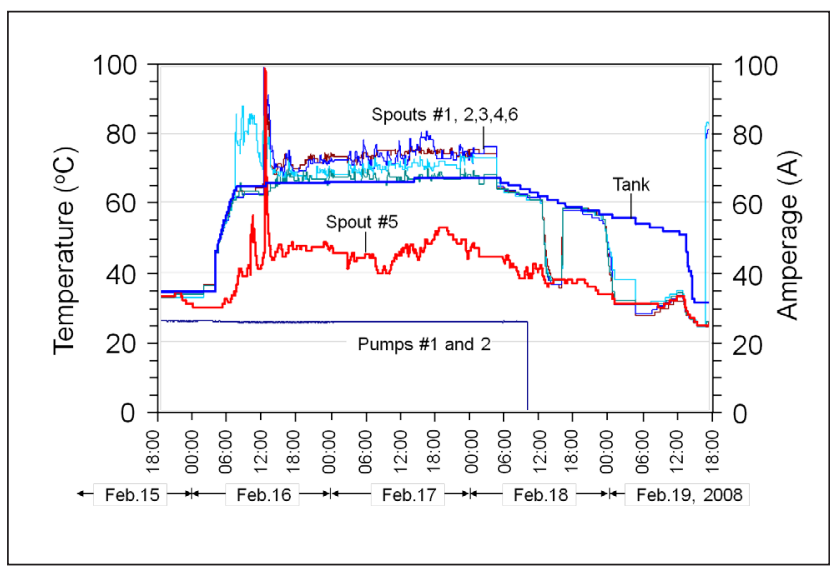

5. Cooling water trends on restart of No. 2 recovery boiler.

head tank. To preserve cooling water flow for a longer time during the blackout, a boiler operator partially closed the hand valve on the main line from the head tank. The operator thought that he closed it halfway, but there was no way to tell if that was actually the case because the hand valve had no marks to indicate the degree of closure. It was not known how much cooling water was flowing to each spout at that time, as there were no flowmeters and it was difficult to check visually.

Figure 4 shows the trend data for the cooling water temperatures from individual spouts and the amperages of the recirculation pumps for the period before and after the blackout. Before the blackout, the cooling water temperature from all six spouts appeared to be normal $\left(70 \pm 3^{\circ} \mathrm{C}\right)$. After the blackout, however, the cooling water temperature of spout No. 5 behaved erratically and was much lower than those of other spouts. This indicates that something had happened to spout No. 5, although it was not noticed at the time because the boiler was down.

\section{February 16, 2008 (boiler startup)}

The mill's No. 1 production line was down for 5 days while the turbo-generator No. 1 was fixed. Only the No. 3 RB operated during this period. The No. $2 \mathrm{RB}$ was started up on February 16,2008 , at 3:10 A.M., and began burning black liquor at 9:40 A.M. During this period, an unusually low and erratic cooling water temperature was noted on spout No. 5, as shown in Fig. 5. This was the first time that the abnormal behavior of spout No. 5 was noted on the DCS, even though it had occurred 5 days earlier. The boiler operator asked for maintenance and was told that the thermocouple in the thermoprobe was bad and needed to be replaced. The thermocouple was checked after the ESP and was found to be normal; no replacement was made.

\section{February 18, 2008 (ESP)}

Because of the inconsistent temperature trends and concerns about the thermocouple, the DCS personnel called on another boiler operator to check spout No. 5 . When passing in front of the spout, the operator saw small explosions inside the fur-

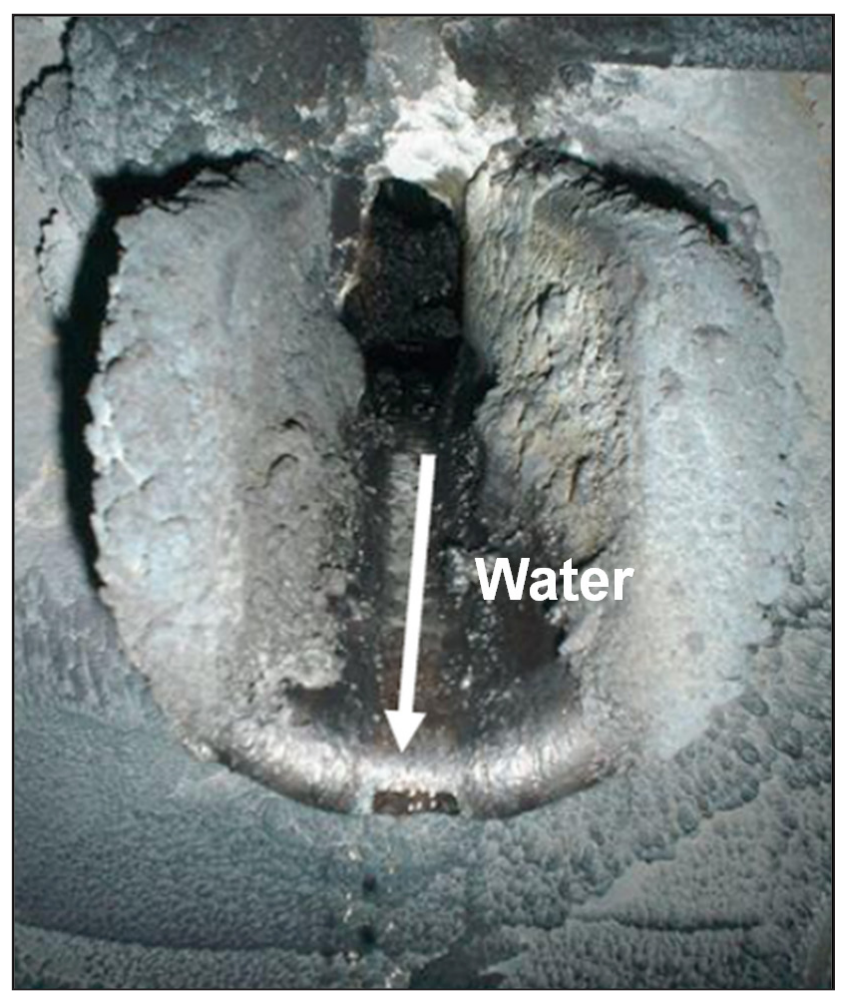

6. Water running out of spout No. 5 from inside the furnace, 12 hours after ESP.

nace; smelt was dark and had stopped flowing. As he started cleaning the spout with a steel lance (as jelly-roll smelt situations are common) he took note of water flowing down the spout trough and darkness of the bed near the spout area. The operator, thinking the water was from a leak on spout No. 5 , shut off the cooling water valve to stop the water flow to that spout. The water, however, kept flowing out from the furnace even after the valve had been closed. The operator then saw the water was sizzling and rumbling inside the furnace and appeared to be coming from a primary air port tube nearby. He immediately called for an ESP, which was initiated at 3:29 A.M. on February 18, 2008.

The boiler was firing 1800 metric tons of black liquor dissolved solids per day when ESP was initiated. The sequence of events shows that the boiler had been burning black liquor with spout No. 5 operated at an usually low cooling water temperature for nearly 2 days before the ESP.

\section{February 19, 2008 (damage inspection)}

An initial inspection at the smelt spout floor about $12 \mathrm{~h}$ after the ESP showed water running down the trough of spout No. 5 from within the furnace, as well as from a hole at the spout lip (Fig. 6). From a man door one floor above the spout floor, a pool of water could be seen around spout No. 5 (Fig. 7). A close look at the rear end of the spout revealed that the inlet and outlet of the cooling water tubing and the trough were completely corroded through, and some water still remained on the trough (Figs. 2 and 7, Fig. 8). 


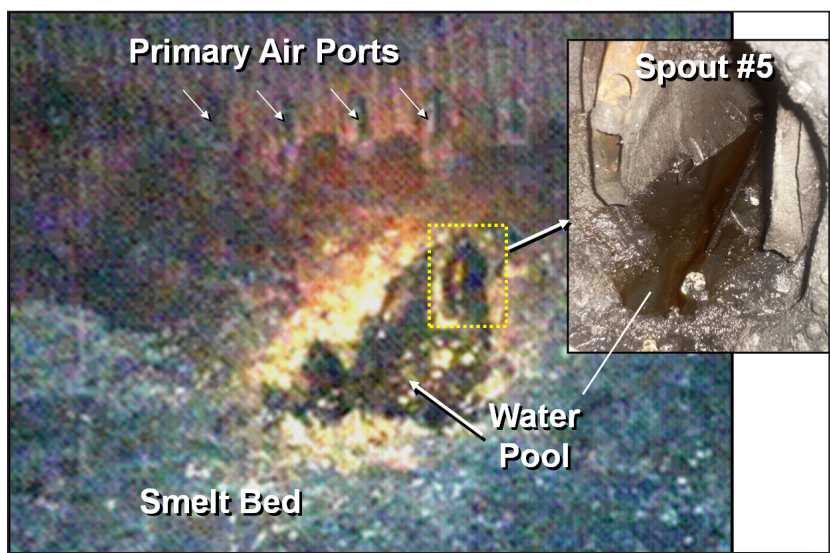

7. Water pool accumulated on frozen smelt bed at the spout No. 5 opening. Box photo shows extensive damage to the cooling water tubing and water on spout trough.

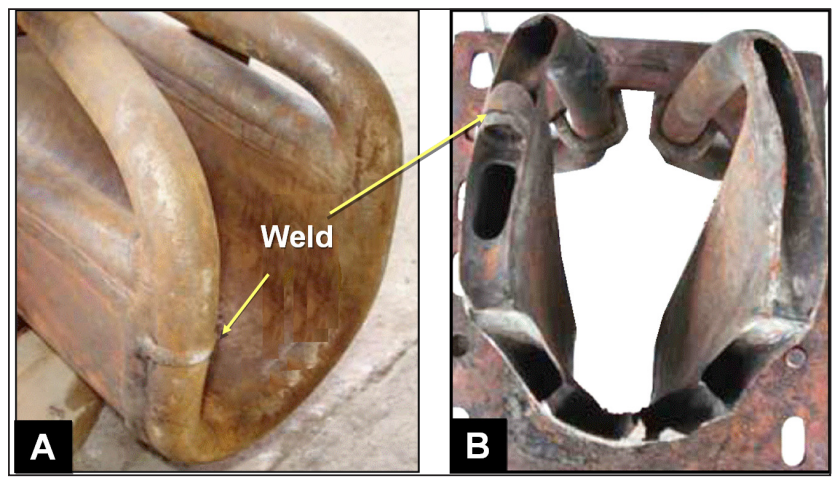

8. (a) Weld connecting the cooling water tube to the spout at the rear end of a good spout; (b) suspected defect on the weld joining the inlet and outlet cooling water tubes of spout No. 5 .

\section{THE INVESTIGATION}

The investigation included a review of event chronology, operator interviews, trend analyses of the No. 2 RB and its spout cooling system operating data, operating procedures of emergency systems, and metallurgical evaluation of corroded and noncorroded spouts. The main focus was on determining the causes of spout failure and devising operational and equipment modifications to avoid a repeat occurrence.

A thorough inspection was conducted on the spout cooling system, particularly the water lines shown in Fig. 3. It was discovered during the inspection that the individual valve identifications were reversed between spouts No. 3 and No. 5, although the identification swap had probably been there since the boiler upgrade in 2004. Therefore, when the operator closed the water valve to spout No. 5 just before the ESP, he in fact shut off the cooling water to spout No. 3. This explains why water continued to enter the furnace through spout No. 5 even though the valve was closed. This also means that spout No. 3 passed through the ESP with no water cooling.

Nondestructive dye-penetrant tests, thickness measurements, and visual inspection were performed on all spouts and waterwall tubes near spout openings. The results showed
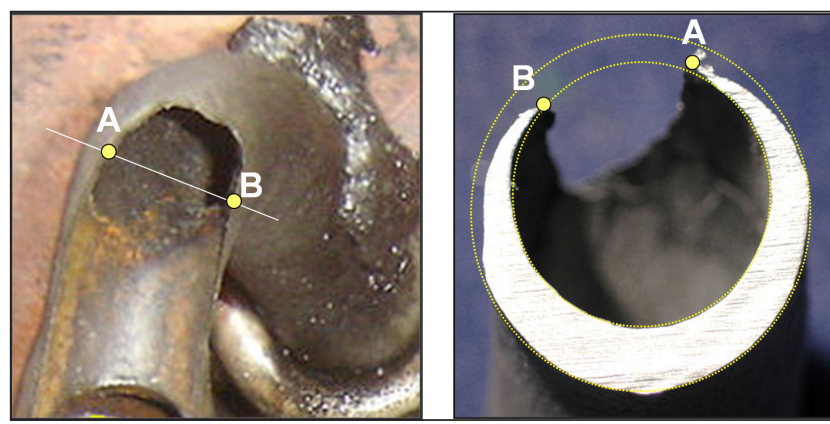

9. Cross-section through a perforation on the cooling water tubing of spout No. 5 showing severe external metal loss. Broken circles are contours of original tube surfaces. The difference in original tube thickness is due to bending.

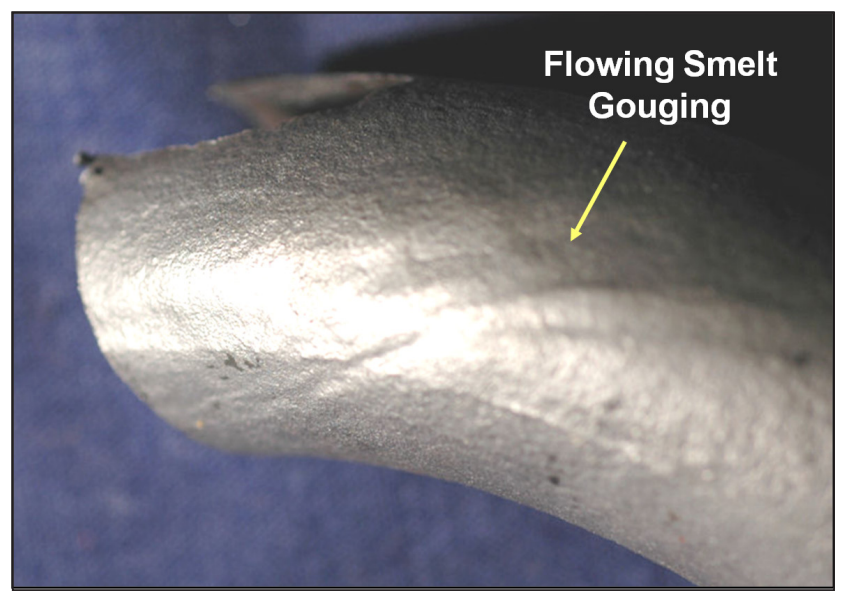

10. Smooth surface of spout No. 5 with signs of gouging by molten smelt.

that waterwall tubes were intact and that spout Nos. 1, 2, 3, 4 , and 6 were in excellent condition with no signs of thinning, cracking, or internal deposits. On spout No. 5, however, in addition to large perforations along the cooling water tubing at the rear end of the spout, there appeared to be a defect in the weld that joined the inlet cooling water tube and the outlet tube.

A large section of spout No. 5 (corroded) and a section of spout No. 3 (not corroded) were also sent to an external laboratory (Nalco Company, Naperville, IL, USA) for metallurgical analysis. The analysis by Nalco revealed that the metal loss of spout No. 5 was mainly from the external surface (Fig. 9). In the areas of severe wastage and along the bottom of the trough, the metal surface was smooth with signs of gouging, resulting presumably from the erosion-corrosion action of molten smelt flowing over the spout surface (Fig. 10). The analysis also revealed that the wastage on spout No. 5 was mainly on the furnace side where heat input is greatest, suggesting a strong temperature dependence of corrosion rates. The microstructure consisted of spheroidized carbides in a ferrite matrix (Fig. 11), suggesting that the metal temperature must have exceeded $540^{\circ} \mathrm{C}\left(1000^{\circ} \mathrm{F}\right)$ for a period of time

Some shallow depressions were also found along the bottom 


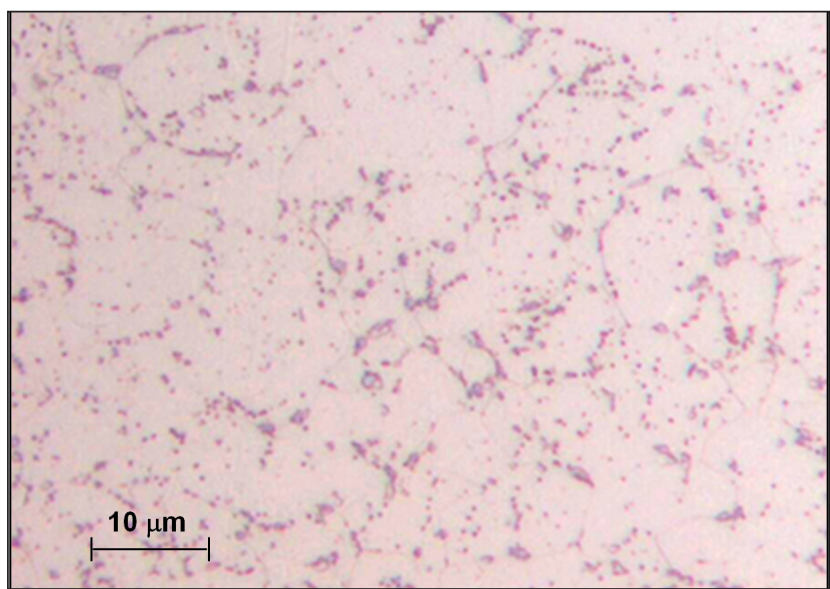

11. Microstructure of the metal near the corroded area of spout No. 5.

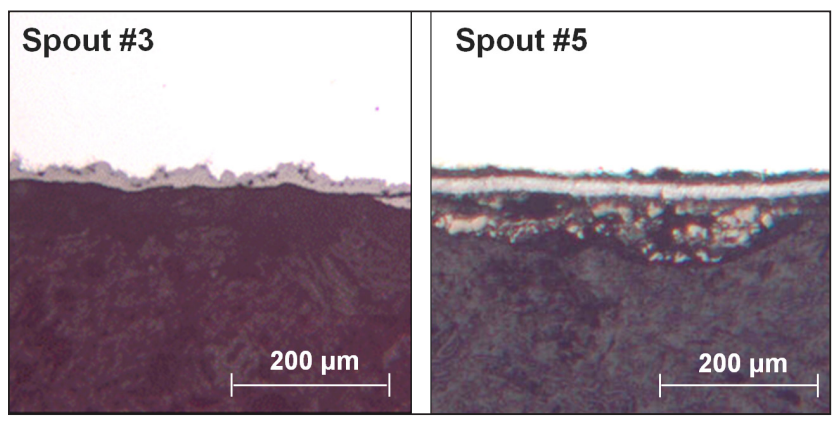

12. Internal surface of spout No. 5 (right) and spout No. 3 (left).

of some cooling water passages. The patterns, however, were characteristic of those caused by idle-time oxygen pitting. This type of corrosion is generally superficial and was unlikely to be the contributing factor in the failure of spout No. 5 .

Although some wastage was also observed along the bottom of the trough of spout No. 3, the extent was insignificant and is expected of a smelt spout that has been in service for 10 months. The internal surface was covered with only a thin and dense layer of oxides (Fig. 12), as opposed to thick layers of deposits and oxides observed on the internal surface of spout No. 5. This implies that spout No. 3 did not experience significant overheating, despite having had its cooling water flow cut off just before the ESP and having been exposed to smelt flow for some time while the ESP was in effect.

\section{INTERPRETATION OF RESULTS}

\section{Causes of failure}

It was apparent from the investigation that (1) the failure of spout No. 5 was caused by excessive overheating of the spout metal surface and the subsequent aggressive attack by flowing smelt, and that (2) the loss of cooling water to that spout was the main reason for the overheating. Some of the overheating occurred during the blackout period, as indicated by the low cooling water temperature from spout No. 5 after the blackout. Overheating also occurred after the boiler was restarted and

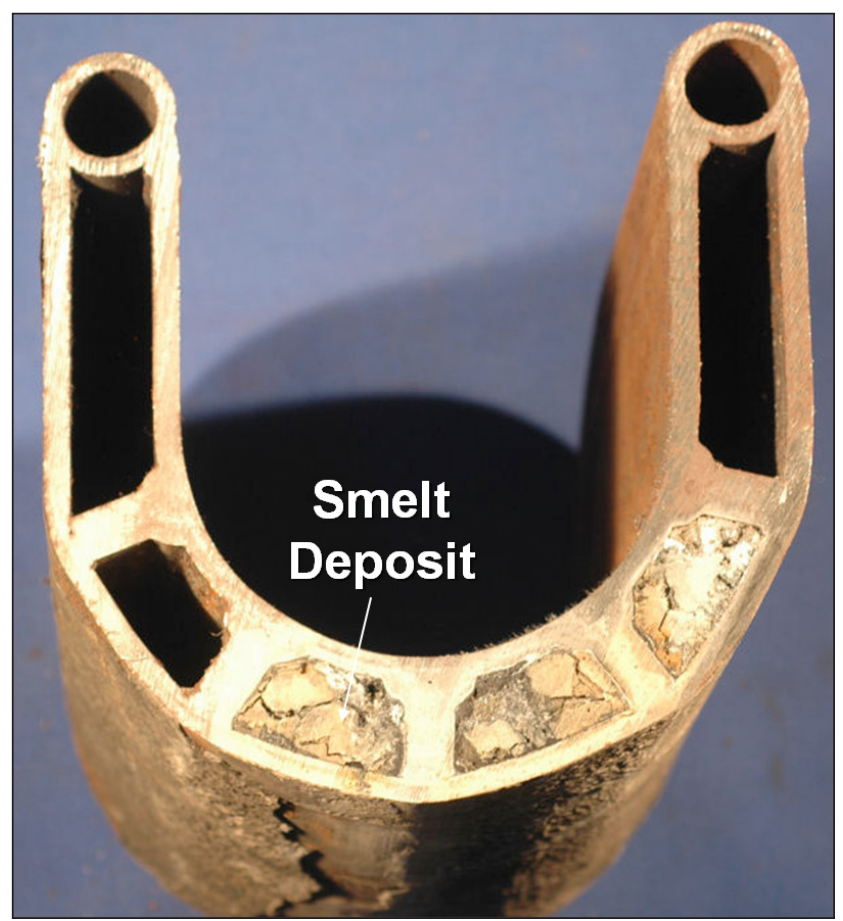

13. Cross-section of spout No. 5, showing smelt deposits locking cooling water passage.

was burning black liquor for nearly 2 days before the ESP. It is unclear, however, which period was more damaging to the spout: during the blackout or during the startup after the ESP

Spout No. 3 operated during the ESP without any cooling water flow and did not experience significant overheating. This, along with the fact that the duration in which all smelt spouts in the No. 2 RB were exposed to molten smelt following the boiler trip (due to power blackout) was about the same as that following the ESP, suggests that the main damage to spout No. 5 did not occur during the boiler trip. However, the cooling water temperature trend data in Figs. 4 and 5 show that spout No. 5 had a much lower cooling-water temperature than other spouts and the collection tank. While it is not known what caused the low cooling water temperature of spout No. 5 during the power blackout, the data suggests that spout No. 5 experienced enough damage that it impaired the cooling water flow through that spout.

The suggested defect found in the weld of spout No. 5 (Fig. 8) may have played a role in its failure. It is possible that the sudden temperature change in the boiler due to the power blackout may have caused the weld to fail, resulting in a small crack through which cooling water leaked out to the furnace. This, in turn, reduced the cooling water flow to the spout, causing it to overheat, and hence, to corrode. As the crack became larger, more water leaked out and less passed through the spout, aggravating the problem further.

In such a scenario, the leaked water begins to accumulate in the furnace near the spout when there is more of it there than it can vaporize. It forms a pool of concentrated smelt solution (saturated green liquor) which pours out the boiler 


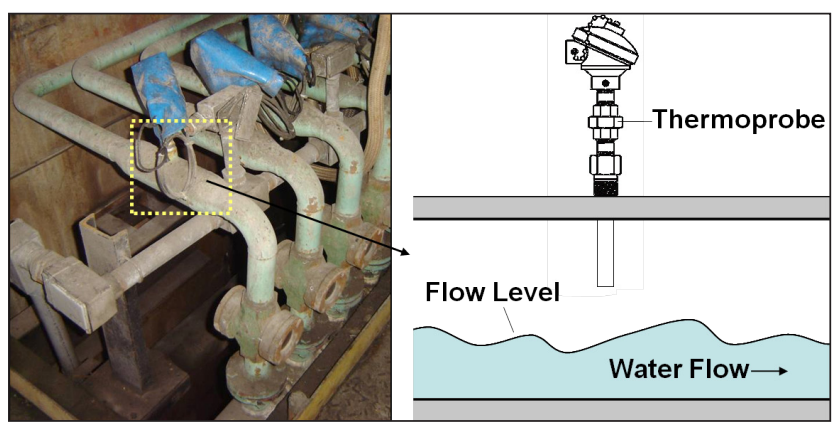

14. Thermoprobe and suspected water level in the cooling water pipe line during the time of reduced flow rate.

through the spout. This concentrated smelt solution can also be detrimental to the spout (carbon steel) for two main reasons: (1) it contains corrosive sodium thiosulfate $\left(\mathrm{Na}_{2} \mathrm{~S}_{2} \mathrm{O}_{3}\right)$ as a result of partial oxidation of sodium sulfide $\left(\mathrm{Na}_{2} \mathrm{~S}\right)$ in the solution, and (2) it cannot vaporize easily due to a boiling point rise and thus can remain as liquid at a temperature as high as $180^{\circ} \mathrm{C}[2]$.

Some smelt solution entered the interior of spout No. 5 , where it re-crystallized to form deposits, leading eventually to complete clogging of cooling water passes, as Fig. 13 shows. The clogging, in turn, impaired the cooling water flow, forcing it to partially bypass the spout and flow directly to the outlet tube. This could be one of the reasons for the lower cooling water temperature of spout No. 5 compared with other spouts.
There are two other possible reasons for the low cooling water temperature. One is the lower flow rate and temperature of molten smelt flowing over the spout because of the cooling effect of leaked water. The other is that due to the reduced flow rate of the cooling water from spout No. 5 , the water level in the pipe line was low, and thus the thermoprobe might not have been able to touch the water to provide proper temperature readings (Fig. 14).

If the low cooling water temperature in spout No. 5 was real (not a result of faulty temperature reading), it may also have contributed to the severe corrosion at the front lip of spout No. 5 (Fig. 2). As shown in Figs. 4 and 5, the cooling water temperature varied between $40^{\circ} \mathrm{C}$ and $50^{\circ} \mathrm{C}$, which was well below the minimum temperature of $60^{\circ} \mathrm{C}$ that a smelt spout must be kept above to avoid dew point corrosion caused by condensation of water vapor from the dissolving tank [3].

In any event, an important factor is that that the cooling water flow to spout No. 5 remained impaired when the boiler was restarted. Overheating of spout No. 5 occurred, and resulted in massive corrosion damage to the spout.

\section{Impact on smelt-water explosion}

The constant drainage of the leaked water from the furnace through the spout prevented accumulation of a large amount of water inside the furnace. The smelt around the spout opening solidified and served as a barrier, isolating the water and preventing it from coming into direct contact with molten smelt. Furthermore, because all six spouts are located under-

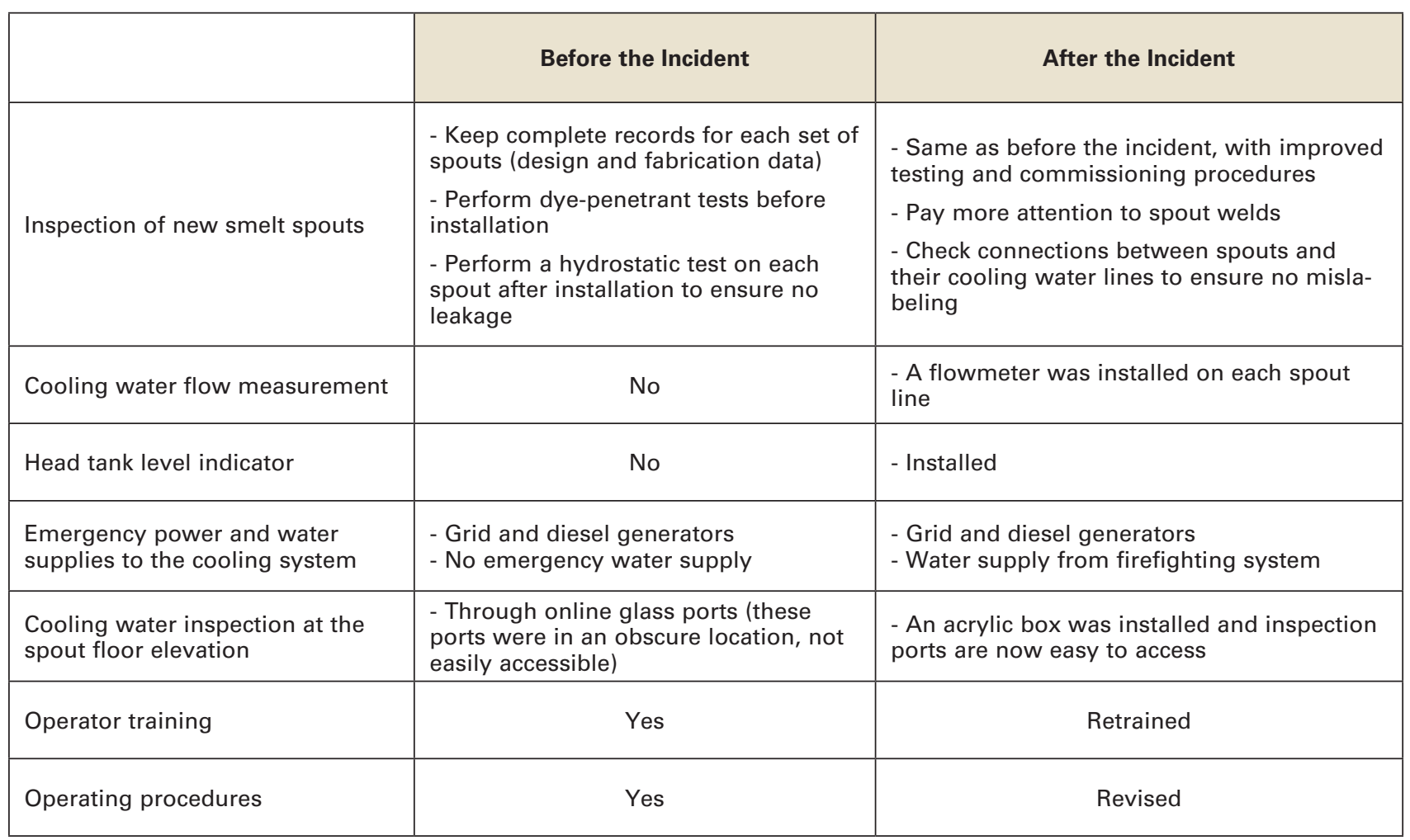


neath a large nose arch (Fig. 1) and the boiler had been down due to a power blackout, the likelihood of falling slag and deposits forcing molten smelt to be in contact with water was small. All of this may help to explain why no smelt-water explosion occurred in this incident.

\section{PREVENTIVE MEASURES}

On the basis of the investigation results, preventive measures have been devised and implemented to prevent a recurrence of the problem. Table I summarizes the main strategy: to provide effective means for more closely monitoring the cooling water system and to help operators inspect water flow at the smelt spout floor more readily. Continuous operator training for handling emergency situations is also one of the important preventive measures. As the last option, water from the mill firefighting system was connected to the upper tank to keep the cooling water system operative during a blackout and failure of the other emergency systems.

\section{CONCLUSIONS}

An extensive investigation was conducted to determine the causes of severe corrosion that led to in-service failure of spout No. 5, one of the six smelt spouts in the No. 2 recovery boiler at Cenibra. The results show that the failure was caused by insufficient cooling water flow to spout No. 5, causing it to overheat and to severely corrode. The insufficient cooling water flow was, in turn, caused by a sequence of events that occurred after a blackout of an electrical energy system at the mill.

Due to the loss of operating data during the power blackout, however, the investigation could not positively determine what actually caused the cooling water flow to decrease in the first place. The theory of a suspected weld defect that may have caused the spout to fail as a result of large temperature changes during the boiler trip is not unreasonable, con- sidering the fact that it was the first time the problem occurred in 32 years of the mill's operating history and that spout No. 5 was the first failure of some 250 smelt spouts that have been used to date. The experience has led to the revision of existing emergency procedures and the development and placement of operating and maintenance procedures that ensure adequate cooling water flow to smelt spouts to prevent future failures. TJ

\section{ACKNOWLEDGEMENTS}

The authors acknowledge the concerted effort and cooperation of many people at Cenibra, including recovery boiler operators, DCS operators, process engineers, and mill management. The authors wish also to acknowledge Nalco Company for its assistance with metallurgical and chemical analyses and Dr. Thomas M. Grace for his valuable comments.

\section{LITERATURE GITED}

1. BLRBAC, "Safe Firing of Black Liquor in Black Liquor Recovery Boilers." Available [Online] www.blrbac.org [April 2009].

2. Tran, H.N., Habibi, B., Kochesfahani, S., et al., 10th International Symposium on Corrosion in the Pulp and Paper Industry, Helsinki, 2001.

3. Tran, H. N., in Kraft Recovery Boilers (T.N. Adams, Ed.), TAPPI PRESS, Atlanta, 1997, pp. 301-302.

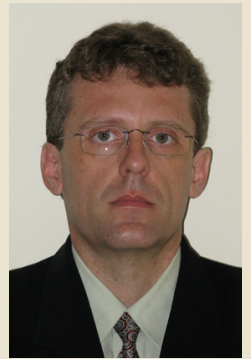

Ribeiro

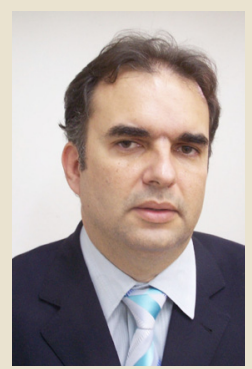

Cardoso

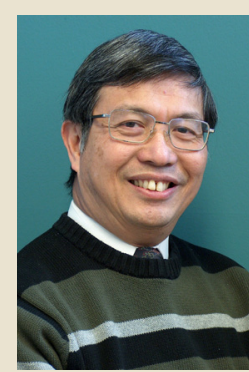

Tran tion in boiler operation and mill productivity. The most surprising finding was that rapid corrosion could occur on only one smelt spout and not others. The information we present may help mills improve their smelt spout cooling systems to prevent spout overheating. We will continue to monitor the smelt spout at the mill.

Ribeiro is with Celulose Nipo-Brasileira S.A., Belo
Oriente, MG, Brazil, and Universidade Federal de Viçosa, Viçosa, Brazil. Cardoso is with the Department of Chemical Engineering/School of Engineering, Federal University of Minas Gerais (UFMG), Belo Oriente, MG, Brazil. Tran is with the Pulp and Paper Centre, University of Toronto, Toronto, ON, Canada. Email Tran at honghi. tran@utoronto.ca. 